Article

\title{
New Approach for Sewage Sludge Stabilization with Ozone
}

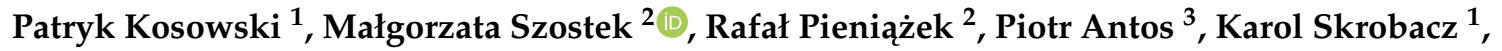 \\ Tomasz Piechowiak ${ }^{1}$, Anna Żaczek ${ }^{4}$, Radosław Józefczyk ${ }^{1}$ and Maciej Balawejder ${ }^{1, *(D)}$ \\ 1 Department of Food Chemistry and Toxicology, Institute of Food Technology and Human Nutrition, \\ University of Rzeszow, St. Ćwiklińskiej 2, 35-601 Rzeszów, Poland; pakosowski@gmail.com (P.K.); \\ karol.skrobacz@gmail.com (K.S.); tom_piech@interia.pl (T.P.); radekjfk@univ.rzeszow.pl (R.J.) \\ 2 Department of Soil Science, Environmental Chemistry and Hydrology, Institute of Agriculture Sciences, \\ Land Management and Environmental Protection, University of Rzeszów, Zelwerowicza 8b, 35-601 Rzeszów, \\ Poland; mszostek@ur.edu.pl (M.S.); rpieniazek45@gmail.com (R.P.) \\ 3 Department of Computer Science in Management, Faculty of Management and Marketing, Rzeszow \\ University of Technology, al. Powstańców Warszawy 8, 35-959 Rzeszów, Poland; piotr_antos@o2.pl \\ 4 Department of Microbiology, Institute of Medical Sciences, University of Rzeszow, Rejtana 16C, \\ 35-959 Rzeszów, Poland; azaczek@ur.edu.pl \\ * Correspondence: maciejb@univ.rzeszow.pl
}

Received: 18 December 2019; Accepted: 22 January 2020; Published: 24 January 2020

\begin{abstract}
Due to a variety of physicochemical properties of the sewage sludge the selection of proper methods for its stabilization is difficult. In this work, the effect of ozone treatment on physico-chemical and microbiological parameters of sludge was investigated. Ozonation was carried out using a counter-current bed reactor, which ensures optimal mass transfer and the contact time of ozone with excessive sediment. The ozonation process was carried out for 15, 30, 45 and 60 min at an ozone concentration of 90-110 ppm. As a result of the ozone treatment it was possible to reduce the number of colony forming units. Also the potential for dewatering of the sludge improved while the total solids of the sludge did not change. The values of COD and $\mathrm{BOD}_{5}$ increased with time of the process.
\end{abstract}

Keywords: sewage sludge; ozonation; stabilization of the sewage sludge

\section{Introduction}

Differentiation of the methods of sludge stabilization, separation, dewatering, as well as the specific nature of the sludge, contribute to volatility in its chemical composition, and various physical properties [1]. The composition and properties of the sewage sludge are the result of many factors, inter alia the initial charge of pollutants in wastewater flowing into the wastewater treatment plant, their temperature, the type of bioreactor, and the application of technological processes of sewage treatment. A significant impact on the composition of the wastewater, and consequently the sewage sludge has a degree of urbanization and industrialization of the agglomerations [2]. A characteristic feature of most of the sewage sludge is their high hydration, which ranges from $99 \%$ in raw excessive sediments to $80-55 \%$ in the dehydrated sediments. This makes them difficult to use e.g., because of the increased transport costs [3]. Sewage sludge is also characterized by a high content of organic carbon and macro and micronutrients, mainly nitrogen and phosphorus, which allows their use as a fertilizer [4]. However a major problem with the utilization of sewage sludge is the significant amount of harmful and toxic substances such as heavy metals or organic contaminants derived from the industry. Sewage sludge is a specific environment that sustains the life of different organisms, and simultaneously it is a are very good substrate for their propagation. Sludge is inhabited by microfauna and microflora, including bacteria, viruses, helminths, fungi, protozoa and other. The sludge is therefore a living 
biomass which is difficult to dewater for different reasons. The variety of chemical and microbiological composition of the sludge makes it necessary to stabilize them, to obtain a product, that is safe from the sanitary point of view. Improvement of the sludge properties can be achieved by pre-treatment of the sludge (conditioning), which aims the fragmentation of the solid sludge. The destruction of the cells of microorganisms included in the sewage sludge causes release of substrates and enzymes essential for further biochemical decomposition of organic compounds by acid phase bacteria and methanogens. Sludge can be conditioned using a variety of methods such as ultrasound, thermal, and in recent years by ozonation or joined methods [5-11]. Ozone treatment is a well-known and proven method of conditioning excessive sludge, but a new solution is constantly being sought that allows the use of ozone gas in heterogenic systems. Most of the proposed solutions (e.g., membrane reactors) aim to maximize the mass exchange between the gas and liquid phase. One such solution may be the use of a counter current flow reactor [12]. In the utilized reactor type ozone is directly contacted with sewage sludge and thus the contact surface between gaseous and liquid phase is expanded on the bed. In the membrane reactor ozone could decompose on surface of membrane or during the compression process, which can reduce efficiency of ozonation process. Ozone as a germicidal agent is more than twice as active as chlorine. Furthermore, ozone degrades a number of compounds believed to cause cancer, such as polycyclic aromatic hydrocarbons and also it is used to remove odor and refractive compounds [13]. In addition, it is widely used in water treatment technology. In the sludge the gas may react with different substances by two coexisting mechanisms. The first is a direct interaction of molecular ozone with an oxidized reagent, and the second is based on consecutive reactions, which are resulting from ozone decomposition. The gas impact on the bacterial cells, is primarily on their outer cell structures, such as the cell membrane. Ozone reacts with components of the cell membrane, i.e., unsaturated fatty acids contained in the lipids. This causes a breakdown of the molecules at the site of a double bond between the carbon atoms therefore resulting in the breakdown of the cell membrane, and consequently outflow of intracellular components to external environment. Ozonation of organic matter causes the formation of peroxides, with a high biochemical activity. One of the major actions of ozone on the cell metabolism is its effect on the coenzymes NADH and NADPH causing their oxidation [14-16]. Ozonation of the sewage sludge was proven to have a significant impact on the sludge properties such as destruction of flocks and reduction of sludge particles [17]. Also the amount of produced biomass is reduced by around 30\% [18]. Among the physical and chemical methods of disruption of the activated sludge the ozonation has the greatest potential for disinfecting and generation of the substrate, resulting not only from the effectiveness in breaking flocs of activated sludge and microbial cells but also from the chemical transformation of released (by cell lysis) organic compounds to the components characterized by higher availability to the specialized microorganisms. Sewage sludge is a burdensome waste product for the natural environment, and its amount will steadily grow [19]. Sludge management must comply with the applicable laws of the European Union and local regulations [19]. Sewage treatment plants have been so far mostly modernized in order to maximize the efficiency of wastewater treatment. Nowadays, the focus should be primarily on solutions limiting the formation of sewage sludge, or that the resulting sludge, would lose the status of waste and could be used as fertilizer, especially that from 1 January 2016 storage of sludge on the lagoons or pits is not allowed [20]. Aside of the environmental factor there is a significant economical factor for sludge treatment. The operating costs of plant used for water treatment involves $25-65 \%$ costs of sludge treatment and disposal [20]. Therefore, there is a need to seek new methods for limiting the formation and stabilization of the sewage sludge. In the study the countercurrent bed reactor, was utilized for the ozonation of sludge originating in the sewage treatment plant in Ropczyce (Podkarpackie Voivodeship, Poland). The parameters such as $\mathrm{pH}$, chemical oxygen demand (COD), biochemical oxygen demand in five days $\left(\mathrm{BOD}_{5}\right)$ and the number of colony forming units of bacteria in the sediment were determined. The aim of this study was to develop of a new countercurrent flow reactor for sewage sludge ozonation which would overcome drawbacks of classical membrane reactors such as low aeration or membrane pollution. 


\section{Materials and Methods}

\subsection{Reagents}

During the physico-chemical analyzes a number of chemical compounds was utilized: sulfuric acid (VI) 95\% p.a. (Chempur Piekary Slaskie, Poland), silver (II) sulphate (VI) p.a. (Stanlab Lublin, Poland), potassium dichromate (VI) p.a. (Poch Gliwice), ammonium and iron (II)sulphate (VI) p.a. (Poch Gliwice, Poland), potassium dihydrogenphosphate (V) p.a. (Chempur Piekary Slaskie, Poland), dipotassiumhydrogenphosphate(V) p.a. (Chempur Piekary Slaskie, Poland), anhydrous disodium hydrogenphosphate(V) p.a. (Chempur Piekary Slaskie, Poland), ammonium chloride p.a. (Chempur Piekary Slaskie, Poland), magnesium sulfate (VI) 7-hydrate p.a. (Chempur Piekary Slaskie, Poland), anhydrous calcium chloride p.a. (Chempur Piekary Slaskie, Poland), iron (III) chloride 6-hydrate p.a. (Chempur Piekary Slaskie, Poland), thiosinamine (POCh Gliwice).

During microbiological tests Nutrient Agar produced by BTL Company Sp. z o.o. (Plant of enzymes and peptones in Lodz, Poland) was used.

\subsection{Collection of Sewage Sludge}

Municipal sewage sludge was collected according to-EN ISO 5667-13: 1997 from the municipal wastewater treatment plant in Ropczyce (Podkarpackie Voivodship, Poland) [21]. Wastewater treatment plant in Ropczyce is a mechanical-biological treatment plant. Sewage flows to the treatment plant through the combined sewage system, and hence domestic wastewater reaches the sewage treatment plant mixed with rainwater, meltwater and other waters. Load of the sewage treatment plant which purifies wastewater using activated sludge, expressed as an population equivalent, is PE $=6396$ [22]. Receiver of sewage is a river Wielopolka.

\subsection{Sewage Sludge Ozonation Procedure}

During the ozonation of sewage sludge the technology proposed by Balawejder et al., was utilized [12] (Figure 1).

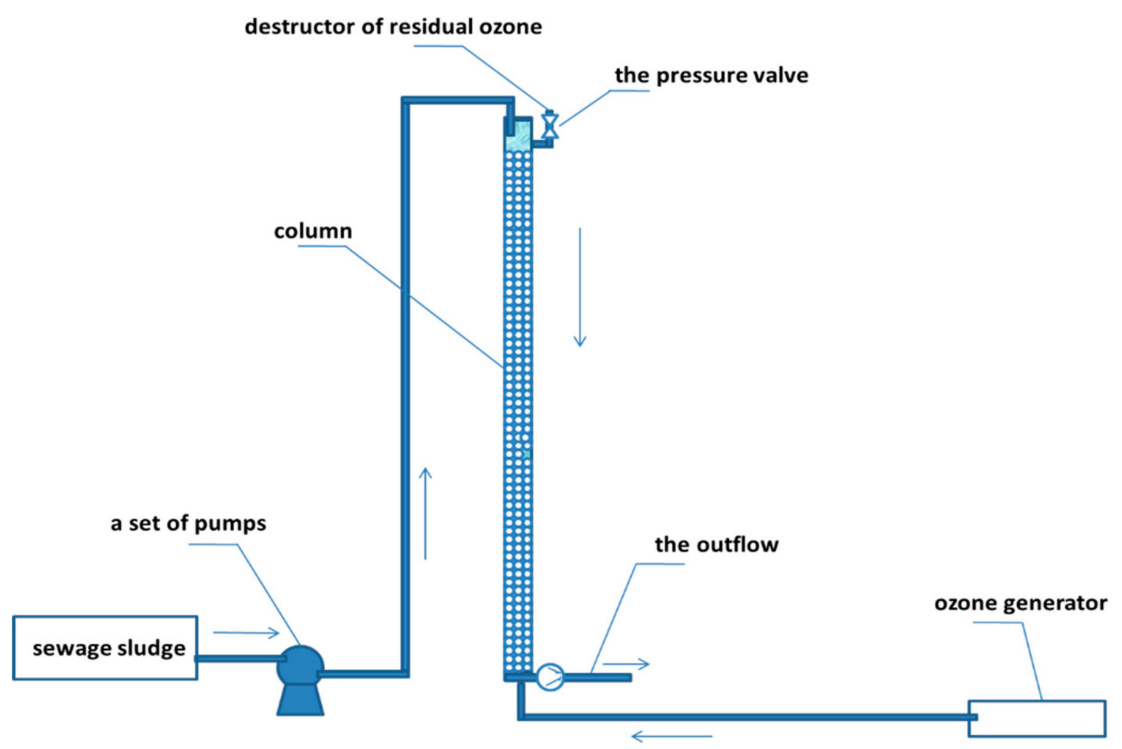

Figure 1. The installation form sludge treatment.

In the proposed method the sewage sludge enters the column $(\phi 0.05 \mathrm{~m} ; 1.2 \mathrm{~m})$ from above thank by peristaltic pomp (max. flow rate $2900 \mathrm{~L} / \mathrm{min}$ ). The specific flow rate of sludge was adjusted to ozonation time. The column is packed bed with plastic fulfillment with a specific surface area $8-10 \mathrm{~m}^{2} / \mathrm{m}^{3}$. Ozone (in a mixture with oxygen) was fed in countercurrent manner, i.e., from the bottom 
of the column. Ozone was generated utilized corona discharge method by the ozone generator TS30 (Ozone Solutions, Hull, IA, USA). The ozone gas pressure was 0.5 bar with flow rate $10 \mathrm{~mL} / \mathrm{min}$. The maximum pressure in the column was controlled by safety valve on 1 bar. The residual ozone that did not react with the sludge was directed to ozone destructor. After the ozonation process was completed, the sludge left the column through the outflow. The ozone concentration during the process was determined on the level between 90 and $110 \mathrm{ppm}$. The ozone concentration was measured with ozone monitor Model 106-L Ozone Monitor (Ozone Solutions, Hull, IA, USA). The sewage sludge ozonation time were 15, 30, 45 and 60 min respectively.

\subsection{Microbiological Analysis}

Nutrient agar (BTL Company Sp. z o.o., Lodz, Poland) which allows the determination the total number of microorganisms grow able in aerobic conditions was utilized. Cultures were made using surface method by a series of dilutions to $10^{-5}$ [23].

\subsection{Analysis of Physiochemical Parameters}

Other parameters of sludge, which were determined according to respective standards were: pH—according to EN 12176: 1998 [24], chemical oxygen demand (COD)—according to ISO 6060:

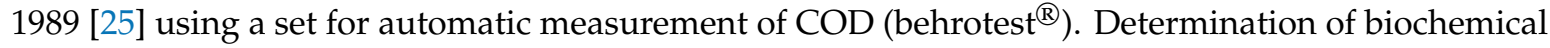
oxygen demand in five days $\left(\mathrm{BOD}_{5}\right)$ was performed according to EN 1899-1: 1998 [26], but for the measurement of dissolved oxygen a device equipped with oxygen sensors: BOD TESTER (Bodt-5) from MRC company was used. Also the mass of total solids of the residue was determined [27] and settleable solid was analyzed by volumetric method, based on the measurement of the volume of settled suspensions in Imhoff funnel after 5, 10, 15, 30, $60 \mathrm{~min}$ [28]. Dewatering of the sludge was measured using sludge baggers Draimad produced by Ekofinn-Pol company. The sludge was introduced to the baggers and left for the gravity induced dewatering. The experiment was conducted three times.

A fast test to verify the efficacy of the process was the turbidance of supernatant measured at $\lambda$ $=595 \mathrm{~nm}$ (blank sample was water), using UV 5100 spectrophotometer of the Biosens company. By analyzing the significance of the effect of the ozonation time on a given quality parameter, one-way ANOVA variation analysis was used, with significance level $\alpha=0.05$. The $t$-Tuckey test for equal numbers was used to verify the hypothesis of significant impact of storage effect on chosen parameter. In addition, Pearson's linear correlation coefficients were calculated between the selected parameters, with significance level $\alpha=0.05$. Statistical analysis was performed using STATISTICA 12 PL [29].

\section{Results}

During the experiment the ozone was used as both a biocide agent and for conditioning of the excessive sludge. The tests results clearly show that the total number of microorganisms, as well as the number of microorganisms grow able on nutrient agar decreases during the ozonation (Figure 2).

Further evidence for inactivation of the sludge microflora is the determined value of settle velocity of sludge presented by decrease of sludge suspensions during the sedimentation (Figure 3).

This effect is probably caused by inactivation of microorganisms belonging to the sludge and the breakdown of sludge flocs, thus allowing the biomass to settle more quickly. After 1 hour of the process reduction of the total number of microorganisms by nearly $2 \log$ cfu g $^{-1}$ was observed (Figure 2). As a result there is a much higher settling velocity of suspensions Imhoff funnel, thereby reducing the apparent viscosity of the sludge [30-32]. Similarly to the effect observed by Park et al. (2003) [8] in our research there was a positive correlation of settling velocity and ozone dose. In addition these results correlate with the microbial analysis, which clearly shows that after 60 minutes of ozonation the number of microorganisms growable on substrates is the lowest. Extrapolating the results of the settleability, allowed drawing conclusion that using sludge conditioning with ozone can significantly shorten the time of the sedimentation of the excess sludge in gravity densifier. 


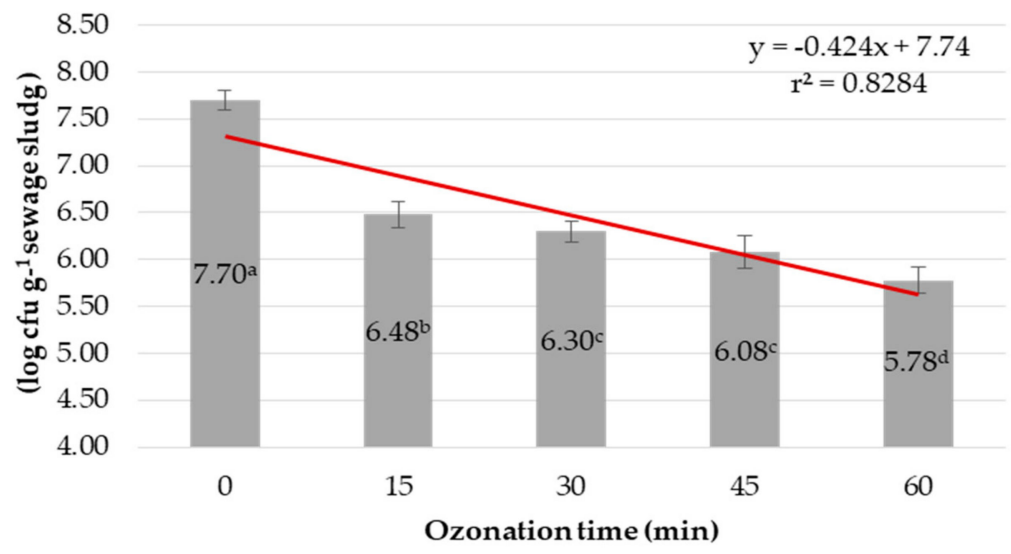

Figure 2. Number of microorganisms growable on nutrient agar depending on the time of ozonation time * * Results are given as mean \pm SD for $n=3$. The mean values marked with the same letter are not statistically important according to t-Tuckey test $(\alpha=0.05)$.

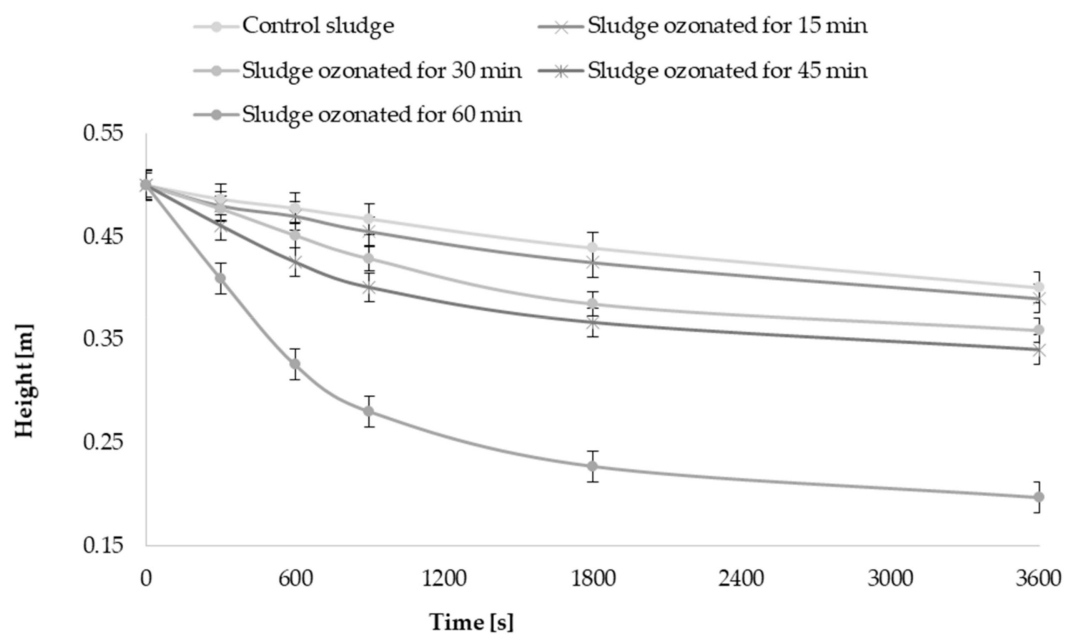

Figure 3. Settleability of sludge depending on the time of ozonation. Results are given as mean \pm SD for $\mathrm{n}=3$.

As indicated in the literature ozone destroys cell membranes by lipid peroxidation and other associated processes, irreversibly changing the structure of other organic compounds [6,32-34]. In addition, it also reacts with the inorganic matter that is part of the sludge. The number of possible processes associated with ozonation is difficult to estimate, but it can be examined macroscopically using typical tests designed to determine of the amount and availability of matter susceptible to oxidation, i.e., $\mathrm{COD}$ and $\mathrm{BOD}_{5}$. The results of these measurements are presented in Table 1.

It has been demonstrated that with an increase of the process duration, the value of COD and $\mathrm{BOD}_{5}$ increases statistically significant. The increase in the values indicates that, with the increase of the ozonation time the destruction process of the sludge progresses. Ozonation process is often used in a wastewater treatment. This process allows $\mathrm{COD}$ and $\mathrm{BOD}_{5}$ removal because the $\mathrm{COD}$ and $\mathrm{BOD}_{5}$ load in wastewater is much lower than in sewage sludge. In case of wastewater the ratio of oxidant to substrates is high enough to allow partial mineralization of contaminants load. The contaminants load in the sewage sludge is only slight converted during the ozonation process. A conversion mechanism is based on sewage sludge flocks disintegration. Ozone is a strong cell-lytic agent, which can kill the microorganisms in sewage sludge and further convert the organic substances released from the cells $[35,36]$. The released organic and inorganic compounds become more bioavailable and thus can be effectively used by aerobic and anaerobic microorganisms. The estimated biodegradability and thus the bioavailability of the sludge is assessed by the $\mathrm{COD} / \mathrm{BOD}_{5}$ ratio. The value of this ratio is inversely 
proportional to sewage sludge biodegradability [36]. The research presented in this study indicates a dynamic increase $(264 \%)$ of $\mathrm{BOD}_{5}$ compare to the almost stable value of COD during the ozonation process. Based on the measurement of dry matter content, it was found that the amount of matter in the sludge does not change, but its form and availability is modified. This is indicated by the decline in the ratio of $\mathrm{COD} / \mathrm{BOD}_{5}$. These parameters allow to state, that the sludge subjected to ozonation process becomes susceptible to further treatment processes, e.g., the further stabilization with oxygen or biogas production [37-39]. At the same time, there were no statistically significant changes in $\mathrm{pH}$ of the sludge. The total solids did not change during the treatment as presented on Table 2.

Table 1. The values of the $\mathrm{pH}, \mathrm{COD}$ and $\mathrm{BOD}_{5}$ of the sewage sludge depending on the time of ozonation *.

\begin{tabular}{|c|c|c|c|c|}
\hline $\begin{array}{l}\text { Time of Sludge } \\
\text { Ozonation (min) }\end{array}$ & $\begin{array}{c}\mathrm{pH} \text { at Temperature } \\
25^{\circ} \mathrm{C}\end{array}$ & $\begin{array}{c}\mathrm{COD} \\
{\left[\mathrm{mg} \mathrm{O}_{2} / \mathrm{L}\right]}\end{array}$ & $\begin{array}{c}\mathrm{BOD}_{5} \\
{\left[\mathrm{mg} \mathrm{O}_{2} / \mathrm{L}\right]}\end{array}$ & COD/BOD 5 \\
\hline 0 & $6.89 \pm 0.07^{\mathrm{a}}$ & $768 \pm 0.52^{a}$ & $93.00 \pm 0.44^{\mathrm{a}}$ & 8.26 \\
\hline 15 & $6.87 \pm 0.07^{a}$ & $826 \pm 0.43^{b}$ & $128.00 \pm 0.46^{b}$ & 6.45 \\
\hline 30 & $6.86 \pm 0.08^{a}$ & $845 \pm 0.48^{c}$ & $143.00 \pm 0.52^{c}$ & 5.91 \\
\hline 45 & $6.83 \pm 0.09^{a}$ & $864 \pm 0.54^{d}$ & $233.00 \pm 0.56^{d}$ & 3.71 \\
\hline 60 & $6.80 \pm 0.08^{a}$ & $922 \pm 0.51^{\mathrm{e}}$ & $338.00 \pm 0.49^{\mathrm{e}}$ & 2.73 \\
\hline
\end{tabular}

* The results are given as mean $\pm S D$ for $n=3$. The mean values marked with the same letter are not statistically important according to t-Tuckey test $(\alpha=0.05)$.

Table 2. Total solids in sludge and settling velocity of sludge particles during ozonation process *.

\begin{tabular}{ccc}
\hline Time of Sludge Ozonation (min) & $\begin{array}{c}\text { Total Solids in the Sewage } \\
\text { Sludge (\%) }\end{array}$ & Settling Velocity (m/s) \\
\hline 0 & $2.244^{\mathrm{a}} \pm 0.058$ & $2.7610^{-5 \mathrm{a}}$ \\
\hline 15 & $2.325^{\mathrm{a}} \pm 0.062$ & $3.0510^{-5 \mathrm{~b}}$ \\
\hline 30 & $2.333^{\mathrm{a}} \pm 0.059$ & $3.9110^{-5 \mathrm{c}}$ \\
\hline 45 & $2.347^{\mathrm{a}} \pm 0.043$ & $4.4310^{-5 \mathrm{~d}}$ \\
\hline 60 & $2.388^{\mathrm{a}} \pm 0.048$ & $8.4110^{-5 \mathrm{e}}$ \\
\hline
\end{tabular}

${ }^{*}$ The results are given as mean \pm SD for $n=3$. The mean values marked with the same letter are not statistically important according to T-Tuckey test $(\alpha=0.05)$.

An additional parameter that was used to determine the efficiency of the sludge ozonation process was the turbidance measurement of the supernatant. The values of settling velocity of sewage sludge and turbidance of supernatant have been shown to decrease with increasing ozonation time (Figure 3). These correlations are confirmed by the high Pearson correlation coefficient between the turbidance of the supernatant and the settling velocity of the sediment, $r=0.94(p<0.05)$, indicating a strong positive correlation. The dependence of turbidance on time and settling velocity is presented in Figure 4 . 


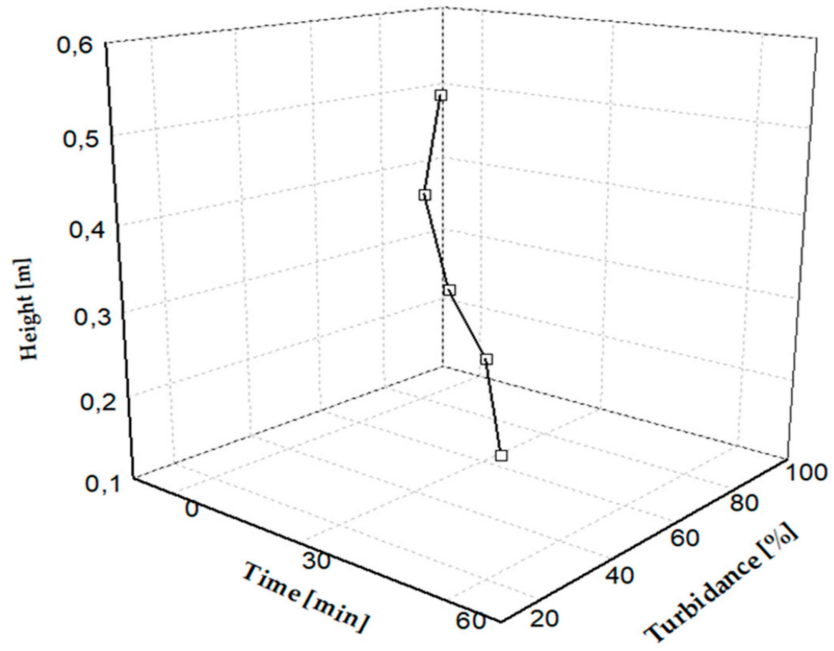

Figure 4. Settleability and turbidance of sludge depending on the time of ozonation. The results are given as mean value for $n=3$.

Measurement of turbidance can be used as a rapid test, which in technological conditions will determine the desired degree of sludge stabilization measured by settling velocity. This measurement takes a few minutes and the full settling velocity test last for an hour (Figure 4). In industrial practice it is possible to install turbidimetric sensors that will allow you to control online the efficiency of the process.

The study indicates the usefulness of the proposed technology. The results obtained in the experimental conditions are encouraging but not all of the parameters are satisfactory. Modifying the conditions, i.e., increasing the time of exposition and the concentration of ozone can solve the problem of low degree of sludge hygienization. The biggest advantages of the proposed technology are:

- Increase of the settling velocity of sludge, which directly affect the amount and cost of sludge dewatering;

- Increase of the biodegradability of matter comprising the sludge, which could have a direct impact on an increase of its usefulness for energy generation (biogas) or in agriculture;

- Countercurrent bed reactor allows the conducting of continues process which is more efficient than processes carried out using batch reactor.

\section{Conclusions}

A countercurrent bed reactor was successfully utilized for ozonation of sewage sludge. As a result the physico-chemical parameters of sewage sludge were modified. The disintegration of sewage sludge flocs was detect as main mechanism of gaseous ozone action. After the ozonation process the settle velocity of sewage sludge increase three times while $\mathrm{COD} / \mathrm{BOD}_{5}$ ratio decrease three times. This observation confirmed disintegration of sewage sludge flocs in proposed ozonation system. Furthermore we also concluded that turbidance measurement of supernatant can be used as a rapid test, which is allow in technological conditions to determine the degree of sludge stabilization measured by settling velocity.

Author Contributions: Conceptualization, methodology and writing—original draft, P.K., M.B, M.S., R.P.; Writing original draft-P.A.; Formal analysis, M.B.; Investigation, R.P., K.S., R.J., A.Ż. and T.P.; Statistical analysis, T.P.; Investigation and writing-original draft, P.K., M.S. All authors have read and agreed to the published version of the manuscript.

Funding: The project was supported by the Minister of Science and Higher Education of Poland (Project No. 026/RID/2018/19 “Regional Initiative of Excellence").

Conflicts of Interest: The authors declare no conflict of interest. 


\section{References}

1. Tujaka, A. Assessment of sewage sludge derived from selected sewage-treatment plants for environmental utilization. ZPPNR 2009, 535, 445-452.

2. Fuerhacker, M.; Haile, T.M. Waste, water and reuse in Mediterranean Region, treatment and reuse of sludge. In The Handbook of Environmental Chemistry; Barceló, D., Kostianoy, D., Eds.; Springer: Berlin/Heidelberg, Germany, 2011; Volume 14, pp. 63-92.

3. Bień, J.D.; Bień, B. Utilization of municipal sewage sludge by thermal methods in the face of storage disallowing. Inżynieria Ekologiczna 2015, 45, 36-43. [CrossRef]

4. Singh, R.P.; Agrawal, M. Potential benefits and risks of land application of sewage sludge. Waste Manag. 2008, 28, 347-358. [CrossRef] [PubMed]

5. Braguglia, C.M.; Gianico, A.; Mininni, G. Comparison between ozone and ultrasound disintegration on sludge anaerobic digestion. J. Environ. Manag. 2012, 95, 139-143. [CrossRef] [PubMed]

6. Byung-Kook, H.; Hyuk-Soo, S.; Jae-Hyuk, K.; Chang, H.A.; Chung-Hak, L.; Jae-Yoon, S.; Young-Hyun, R. Decomposition of excess sludge in a membrane bioreactor using a turbulent jet flow ozone contactor. J. Ind. Eng. Chem. 2010, 16, 602-608. [CrossRef]

7. Długosz, J.; Gawdzik, J. The content of heavy metals in sewage sludge conditioned CaO. Archiwum Gospodarki Odpadami i Ochrony Środowiska 2014, 16, 49-56.

8. Park, K.Y.; Ahn, K.-H.; Maeng, S.K.; Hwang, J.H.; Kwon, J.H. Feasibility of sludge ozonation for stabilization and conditioning. Ozone Sci. Eng. 2003, 25, 73-80. [CrossRef]

9. Tian, X.; Wang, C.; Prandota-Trzcinski, A.; Lin, L.; Ng, W.J. Interpreting the synergistic effect in combined ultrasonication-ozonation sewage sludge pre-treatment. Chemosphere 2015, 140, 63-71. [CrossRef]

10. Xu, G.; Chen, S.; Shi, J.; Wang, S.; Zhu, G. Combination of ultrasound and ozone for improving solubilization and anaerobic biodegradability of waste activated sludge. J. Hazard. Mater. 2010, 180, 340-346. [CrossRef]

11. Otieno, B.; Apollo, S.; Kabuba, J.; Naidoo, B.; Simate, G.; Ochieng, A. Ozonolysis pre-treatment of waste activated sludge for solubilization and biodegradability enhancement. J. Environ. Chem. Eng. 2019, 7, 102945. [CrossRef]

12. Balawejder, M.; Kosowski, P.; Szostek, M.; Pieniążek, R. Device for Sludge Ozonation. Patent P.416306, 11 September 2017.

13. Bernal-Martinez, A.; Carrère, H.; Patureau, D.; Delgenès, J.P. Ozone pre-treatment as improver of PAH removal during anaerobic digestion of urban sludge. Chemosphere 2007, 68, 1013-1019. [CrossRef] [PubMed]

14. Inchauste-Daza, A.; Saroj, D.; Lopez-Vazquez, C.M.; Brdjanovic, D. Ozonation for sludge reduction and improved biological nutrient removal. J. Residuals Sci. Technol. 2011, 8, 71-78.

15. Yan, S.T.; Chu, L.B.; Xing, X.H.; Yu, A.F.; Sun, X.L.; Jurcik, B. Analysis of the mechanism of sludge ozonation by a combination of biological and chemical approaches. Water Res. 2009, 43, 195-203. [CrossRef] [PubMed]

16. Michałkiewicz, M.; Jeż-Walkowiak, J.; Dymaczewski, Z.; Sozański, M. Wastewater disinfection. Inżynieria Ekologiczna 2011, 24, 38-51.

17. Chu, L.; Yan, S.; Xing, X.-H.; Sun, X.; Jurcik, B. Progress and perspectives of sludge ozonation as a powerful pretreatment method for minimization of excess sludge production. Water Res. 2009, 43, 1811-1822. [CrossRef]

18. Fall, C.; Silva-Hernandez, B.C.; Hooijmans, C.M.; Lopez-Vazquez, C.M.; Esparza-Soto, M.; Lucero-Chavez, M.; van Loosdrecht, M.C.M. Sludge reduction by ozone: Insights and modeling of the dose response effects. J. Environ. Menag. 2018, 206, 103-112. [CrossRef]

19. National Plan for Waste Management for Poland 2022; Annex to the Resolution No 88 of the Council of Ministers of 1 July 2016 (item 784); Ministerstwo Klimatu: Warszawa, Poland, 2016.

20. Regulation of the Minister of Economy of 8 January 2013 on the Criteria and Procedures for the Acceptance of Waste for Disposal at a Landfill of a Particular Type. J. Laws Repub. Pol. 2013, 38. (in Polish).

21. European Committee for Standardization. Water Quality-Sampling -Part 13: Guidance on Sampling of Sludges from Sewage and Water Treatment Works; EN ISO 5667-13; European Committee for Standardization: Brussels, Belgium, 1997.

22. Council Directive of 21 May 1991 Concerning Urban Waste Water Treatment (91/271/EEC). Counc. Eur. Communities Off. J. Eur. Communities 1991, No. L 135, 40-52. 
23. Budzińska, K.; Jurek, A.; Michalska, M.; Berleć, K.; Szejniuk, B. Dynamics of changes in bacterial microflora of stored sewage sludge (in Polish). Roczniki Ochrony Środowiska 2009, 11, 1157-1164.

24. European Committee for Standardization. Characterization of Sludge. Determination of pH Value; EN 12176; European Committee for Standardization: Brussels, Belgium, 1998.

25. ISO. International Organization for Standardization Water quality-Determination of the Chemical Oxygen Demand; ISO 6060; ISO: Geneva, Switzerland, 1989.

26. European Committee for Standardization. Water Quality_Determination of Biochemical Oxygen Demand after $n$ Days $\left(B O D_{n}\right)$. Dilution and Seeding Method with Allylthiourea Addition; EN 1899-1; European Committee for Standardization: Brussels, Belgium, 1998.

27. European Committee for Standardization. Characterization of Sludges. Determination of Dry Residue and Water Content; EN 12880; European Committee for Standardization: Brussels, Belgium, 2000.

28. European Committee for Standardization. Characterization of Sludges. Settling Properties. Determination of Settle Ability (Determination of the Proportion of Sludge Volume and Sludge Volume Index); EN 14702-1; European Committee for Standardization: Brussels, Belgium, 2006.

29. STATISTICA 12 Pl. Available online: http://www.statsoft (accessed on 1 October 2019).

30. Bougrier, C.; Albasi, C.; Delgenès, J.P.; Carrère, H. Effect of ultrasonic, thermal and ozone pre-treatments on waste activated sludge solubilisation and anaerobic biodegradability. Chem. Eng. Process. 2006, 45, 711-718. [CrossRef]

31. Królak, E.; Biardzka, E.; Łapińska, R.; Semeniuk, A. Stężenie związków biogennych w osadach ściekowych i wodach odciekowych wytwarzanych w gminnych oczyszczalniach ścieków (Łomazy i Sławatycze). Inżynieria i Ochrona Środowiska 2014, 17, 211-219.

32. Nowicka, E.; Grubel, K.A.; Machnicka, A. Improving the gravitational properties of sewage sludge by pretreatments. Inżynieria Ekologiczna 2015, 41, 90-96. [CrossRef]

33. Chu, L.; Wang, J.; Wang, B.; Xing, X.H.; Yan, S.; Sun, X.; Jurcik, B. Changes in biomass activity and characteristics of activated sludge exposed to low ozone dose. Chemosphere 2009, 77, 269-272. [CrossRef] [PubMed]

34. Zhang, G.; Yang, J.; Liu, H.; Zhang, J. Sludge ozonation: Disintegration, supernatant changes and mechanisms. Bioresour. Technol. 2009, 100, 1505-1509. [CrossRef] [PubMed]

35. Cui, R.; Jahng, D.J. Nitrogen control in AO process with recirculation of solubilized excess sludge. Water Res. 2004, 38, 1159-1172. [PubMed]

36. Saktaywin, W.; Tsuno, H.; Soyama, T.; Weerapakkaroon, J. Advanced sewage treatment process with excess sludge reduction and phosphorus recovery. Water Res. 2005, 39, 902-910. [CrossRef]

37. Hoffland, R.O. Method and Apparatus for Treating Animal Waste and Wastewater. Patent US 7005068 B2, 28 February 2006.

38. Knobloch, M.; Schmidt, A.; Koch, R.; Peukert, V. Process and Apparatus for Treating Wastewater from Oil Plant Processing and Cereal Processing. Patent US 6391202 B1, 21 May 2002.

39. Packyama, G.S.; Kavithaa, S.; Kumara, S.A.; Kaliappanb, S.; Yeomc, I.T.; Banua, J.R. Effect of sonically induced deflocculation on the efficiency of ozone mediated partial sludge disintegration for improved production of biogas. Ultrasonics Sonochemistry 2015, 26, 241-248. [CrossRef]

(C) 2020 by the authors. Licensee MDPI, Basel, Switzerland. This article is an open access article distributed under the terms and conditions of the Creative Commons Attribution (CC BY) license (http://creativecommons.org/licenses/by/4.0/). 